\title{
O ALÉM DOS QUE ESTÃO ALÉM-MAR: O PROBLEMA DA SALVAÇÃO DOS ÍNDIOS EM FRANCISCO SUÁREZ
}

\author{
Bento Machado Mota ${ }^{1}$
}

Resumo: Este artigo pretende examinar o pensamento de Francisco Suárez frente a salvação dos gentios a partir do conceito de ignorância invencível. Esta categoria foi definida por Aquino e foi atribuída àqueles que não conheceram e nem puderam conhecer a Deus, sendo reinterpretada por Suárez nos seiscentos para, entre outras coisas, escrever sobre a salvação daqueles que desconheciam Deus. Para tanto, pretendemos trabalhar com suas principais obras de teologia moral no contexto intelectual em que estava inserido, em especial em suas polêmicas com os dominicanos. Assim, procuramos compreender as polêmicas filosóficas e religiosas em que esteve envolvido para compreender as penalidades dirigidas àqueles que ignoravam a Deus e a lei natural em solo americano.

Palavras-chave: Segunda Escolástica. Francisco Suárez. Ignorância invencível. Soteriologia. Ameríndios.

\section{THE BEYOND THOSE BEYOND THE SEA: THE PROBLEM OF THE SALVATION OF THE INDIANS IN FRANCISCO SUÁREZ}

\begin{abstract}
This article aims to examine the thinking of Francisco Suárez regarding the salvation of the Gentiles as from the concept of invincible ignorance. This category was defined by Aquino and was attributed to those who did not know and could not know God, being reinterpreted by Suárez in the 1600s to, among other things, write about the salvation of those who did not know God. To this end, we intend to work with his main works of moral theology in the intellectual context in which he was inserted, especially in his polemics with the Dominicans. Thus, we intend to understand the philosophical and religious controversies in which he was involved in order to understand the penalties directed at those who ignored God and natural law on American soil.
\end{abstract}

Keywords: Second Scholastic. Francisco Suárez. Invincible ignorance. Soteriology. Amerindians.

\section{L'AU-DELÀ DE CEUX AU-DELÀ DE LA MER : LE PROBLÈME DU SALUT DES INDIENS FRANCISCO SUÁREZ}

Résumé: Cet article vise à examiner la pensée de Francisco Suárez concernant le salut des Gentils du concept de l'ignorance invincible. Cette catégorie a été définie par Aquino et a été attribuée à ceux qui ne connaissaient pas et ne pouvaient pas connaître Dieu, réinterprétée par Suárez dans les années soixante pour, entre autres, écrire sur le salut de ceux qui ne connaissaient pas Dieu. À cette fin, il entend travailler avec ses principaux travaux de théologie morale dans le contexte intellectuel dans lequel il s'est inséré, notamment dans ses polémiques avec les dominicains. Ainsi, il entend comprendre les controverses philosophiques et religieuses dans lesquelles il a été impliqué afin de comprendre les sanctions infligées à ceux qui ont ignoré Dieu et la loi naturelle sur le sol américain.

Mots-clés: Second scolastique. Francisco Suárez. Ignorance invincible. Sotériologie. Amérindiens.

\footnotetext{
${ }^{1}$ Doutorando em História Social pela Universidade de São Paulo, orientado pelo Professor Doutor Adone Agnolin.
}

Revista Escritas do Tempo - v. 1, n. 3, nov/2019-fev/2020 - p. 34-54 


\section{EL MÁS ALLÁ DE LOS QUE ESTÁ ALLÁ DEL MAR: EL PROBLEMA DE LA SALVACIÓN DE LOS INDIOS EM FRANCISCO SUÁREZ}

Resumen: Este artículo tiene como objetivo examinar el pensamiento de Francisco Suárez con respecto a la salvación de los gentiles del concepto de ignorancia invencible. Aquino definió esta categoría y se atribuyó a aquellos que no conocían y no podían conocer a Dios, siendo reinterpretada por Suárez en los años sesenta para, entre otras cosas, escribir sobre la salvación de aquellos que no conocían a Dios. Con este fin, tiene la intención de trabajar con sus principales obras de teología moral en el contexto intelectual en el que se insertó, especialmente en sus polémicas con los dominicanos. Por lo tanto, tiene la intención de comprender las controversias filosóficas y religiosas en las que estuvo involucrado para comprender las penas dirigidas a aquellos que ignoraron a Dios y la ley natural en suelo estadounidense.

Palabras clave: Segundo escolástico. Francisco Suárez. Ignorancia invencible. Soteriología. Amerindios.

\section{Introdução}

Francisco Suárez foi o maior expoente do pensamento jesuítico do século XVII. Os maiores intérpretes de sua obra - desde Hobbes, Heidegger até Richard Morse ${ }^{2}$ - o reconhecem como um dos maiores modelos da ortodoxia tomista católica. Há, contudo, territórios de sua obra que seguem pouco explorados. Tais lacunas ajudam a compreender tensões e limites de seu pensamento, que marcou profundamente a produção teológica ulterior e as diretrizes missionárias no novo mundo. Um desses territórios inexplorados é o debate em torno da ignorância invencível dos índios. Neste tema, ao invés de Suárez ter sido acusado de ortodoxo, seus argumentos frequentemente foram identificados, inversamente, como pelagianos, probabilistas e, mais tarde, "laxistas".

Este artigo pretende examinar o pensamento de Francisco Suárez frente a salvação dos gentios a partir do conceito de ignorância invencível. O fio condutor será a ignorância invencível, conceito criado por Tomás de Aquino para designar aqueles que não conheciam e nem poderiam conhecer aquilo que deveriam. Segundo Aquino, este grupo não poderia ser condenado porque este tipo de ignorância os insentaria da responsabilidade sobre os próprios atos. Em outras palavras, ele poderia isentar os ignorantes do cumprimento da Lei natural e mesmo do conhecimento de Deus. Após o contato com os povos ameríndios, este conceito tornou-se uma das principais categorias para se definir se os índios poderiam ser salvos ou não. Ao examinar tal conceito na obra de Francisco Suárez, trabalhamos as penalidades relativas àqueles que desconheciam a Deus e/ou a Lei natural.

2 Thomas Hobbes, Gottfried Leibniz, Arthur Schopenhauer e Martin Heidegger comentaram explicitamente a obra de Suárez. Ver: SCHMUTZ, 2004 a, p. 5-16 e SGARBI, 2010. Sobre a relação do tomismo com aspectos sociológicos no Brasil, ver o ensaio de Morse (1988).

Revista Escritas do Tempo - v. 1, n. 3, nov/2019-fev/2020 - p. 34-54 
Para tanto, o presente artigo divide-se em quatro partes. Na primeira, trabalhamos o debate entre dominicanos e jesuítas em fins do século XVI e princípios do século XVII, conhecido como a polêmica De Auxillis. Na segunda, dialogamos com o conceito de ignorância invencível diante de Deus, no caso dos ameríndios, a partir de algumas obras de Francisco Suárez. Na terceira, examinamos a ignorância diante da Lei. Ao final, tecemos algumas considerações sobre os limites, dentro do campo da teologia moral, da salvação daqueles que ignoram Deus.

\section{Jesuítas e Dominicanos debatem a justificação}

$\mathrm{Na}$ guerra teológica do tempo de Francisco Suárez, três grandes batalhas ocorriam concomitantemente: os conflitos entre nominalistas e realistas ${ }^{3}$, a emergência do protestantismo e os problemas correlatos à conquista americana. Contudo, após a realização do Concílio de Trento ${ }^{4}$, outro front se abriu, mas desta vez âmbito católico ${ }^{5}$. Como bem sintetizou Jean Delumeau, as definições do concílio de Trento buscarem tornar equidistantes o otimismo dos pelagianos e o pessimismo dos luteranos (DELUMEAU, 1971, p. 75).

No cânone, no sexto decreto, por exemplo, se lê: "se alguém disser, que o homem pode se salvar para com Deus por suas próprias obras, feitas com apenas as forças da natureza, ou por doutrina da lei, sem a graça Divina, conseguida por Jesus Cristo, seja excomungado". Por outro lado, no quinto decreto, se estabelece: "se alguém disser, que o livre arbítrio do homem foi perdido e extinguido depois do pecado de Adão, ou que é coisa só de nome, sem importância e sem função, introduzida pelo demônio na Igreja, seja excomungado" .

A condenação de que o homem não pode cumprir a lei natural por si mesmo e a refutação de que não existe o livre-arbítrio do homem constituíram-se como balizas de duas heresias opostas. Tais disputas tiveram fortes implicações no debate sobre a ignorância, pois se o homem pode ser salvo por seu arbítrio, então os ignorantes teriam alguma chance de alcançar a vida eterna. Em contraste, se a salvação ocorre

\footnotetext{
${ }^{3}$ Para a relação entre Suárez e os nominalistas, ver: CROSS, 2005, pp. 65-80.

4 Para o Concílio de Trento, ver: PROSPERI, 2008. Para outras referências, ver: TALLON, 2010; SGARBI, 2010.

${ }^{5}$ A ideia de que os jesuítas estavam em guerra foi utilizada por Gay (2012).

${ }^{66} \mathrm{Si}$ quis liberum hominis arbitrium post Adæ peccatum amissum et exstinctum esse dixerit, aut rem esse de solo titulo, immo titulum sine re, figmentum denique a satana invectum in Ecclesiam: anathema sit, in: http://www.documentacatholicaomnia.eu/04z/z 1545-1563 Concilium Tridentinum Sessio_VIDecretum_de_Justificatione_LT.doc.html. Acesso em: 20 set. 2019.
} 
exclusivamente pela graça, aqueles que a desconhecem não podem salvar-se e não têm condição de fazer nenhum bem sem Deus.

Mas, tais fronteiras ainda pareciam amplas demais no território da história das ideias espirituais, cujo cenário terminou por se constituir em um violento campo de batalhas em fins do século XVI e por todo o século XVII. A dupla condenação não foi suficiente para tornar finita a imortal polêmica pelagiana e muito menos erradicar a heresia protestante. Não obstante as tentativas de conciliação de Domingo Soto ${ }^{7}$, não se obteve consenso sequer entre católicos.

Segundo Vicente Beltran de Heradia, grande estudioso do tema, nos anos pósconcílio os dominicanos tornaram-se cada vez mais ortodoxos, ao passo que os jesuítas ganharam mais espaço para se desenvolverem intelectualmente (HERENDIA, 1968, p. 45). Foi nesse contexto que Luís de Molina buscou uma nova interpretação a partir de sua célebre Concordia liberi arbitrii cum gratia donis, diuina prascientia, prouidentia, pradestinatione, et reprobatione $(1588)^{8}$. De forma sintética, Luís de Molina defendeu que a prescientia de Deus sobre os atos humanos não pode causar um efeito de necessidade, sendo preciso, para existir o livre-arbítrio, que haja algum nível de contingência.

A grande dificuldade seria compreender que a justificação do homem deveria depender da vontade livre de Deus, de um lado, e a vontade livre do homem, de outro. Sua proposta foi a de que Deus teria dado a todos os homens a possibilidade de se salvarem através da graça suficiente ${ }^{9}$. Os homens, porém, dotados de livre-arbítrio, poderão recusá-la. Entretanto, como Deus possui a prescientia dos futuros contingentes, ele poderia prever quem a recusaria ou aceitaria, concedendo apenas a estes a graça eficiente, isto é, a única que poderia garantir a salvação. Esta conciliação entre livrearbítrio e graça, dentro da qual Deus conhece de antemão as ações humanas, mas não é responsável por elas, é conhecido como scientia media ${ }^{10}$.

\footnotetext{
7 Domingo de Soto (1496-1560) foi professor de teologia de Carlos V e, na condição de sucessor de Vitória, foi o dominicano com maior prestígio no concílio de Trento. A respeito do debate sobre a graça e sua relação com os debates que envolvem o livre-arbítrio, ver: STEGMÜLLER, 1934, p. 166-482; BERMEJO, Ignacio Jericó. El pecado de infidelidad. Su relación con la conve rsión y la justificación en Domingo Báñez (1584), Naturaleza y Gracia 48/1-2 (2001), 65-90. Além disso, continua clássica a obra de Heredia (1922).

${ }^{8}$ MOLINA, 2007. Para sua relação com a polêmica De Auxillis em geral, ver: DÍAZ-ALEGRÍA, 1951; SCHMAUS, 1959; BONET, 1932.

${ }^{9}$ Graça suficiente refere-se ao auxílio divino necessário para alcançar a salvação.

${ }^{10}$ Conforme Molina (2007, p. 506-507): "afirmamos que toda la certeza de la ciencia divina por medio de la cual Dios presabe que, sin lugar a dudas, van a producirse los actos - tanto buenos, como malos - del arbitrio creado, no procedería exclusivamente de las predefiniciones de conferir auxilios y concursos -
} 
Os jesuítas Roberto Bellarmino e Leonardo Lessius posicionaram-se a favor da proposta de Molina. Aos olhos dos dominicanos, contudo, tal proposta de concórdia lhes pareceu declaração de uma guerra civil, porque trazia consigo a possibilidade do homem salvar-se por si mesmo, trazendo traços da posição pelagiana para o seio da ortodoxia católica. Segundo Domingo Bañez, o principal dominicano do outro lado da batalha, o conceito de ciência média deturpava o real sentido interpretativo da sagrada escritura e de Santo Agostinho. A reação não tardou: sete anos depois, o poderoso Domingo Bañez escreveu uma Apologia dos dominicanos em defesa da graça (BAÑEZ, 2002).

Sob o reinado de Felipe II, os embates vivenciados por Lutero e Erasmo, algumas décadas antes, pareciam repetir-se no cenário católico pós-tridentino. Em virtude da importância dogmática de tais debates, o pontífice Clemente VIII responsável pela condenação à fogueira de Giordano Bruno -, esteve presente nas disputas (ECHEVARRÍA, 2002, pp. 11-12). Durante tais reuniões, contudo, a física violência chegou a um nível tão descontrolado que numa das sessões, em 1602, o pontífice foi acometido por um enfarto e faleceu. Cinco anos depois, após disputas intermináveis, Paulo V, sucessor de Clemente VIII, considerou que nenhuma das concepções poderia ser considerada herética.

Na prática, esta resolução dignificou a vitória de Molina e dos jesuítas, levandose em conta a repercussão posterior de sua obra no mundo cristão. Esta querela ficaria conhecida como Polemica de Auxillis ${ }^{11}$. A disputa em torno da predestinação e do livrearbítrio, contudo, estava longe de terminar. Seria retomada poucos anos depois em solo protestante, no debate arminianista-calvinista ${ }^{12} \mathrm{e}$, novamente, a partir do ataque avassalador dos Jansenistas contra a companhia de Jesus.

A produção de Francisco Suarez foi profundamente marcada por essa e outras controvérsias, nas quais esteve diretamente envolvido ${ }^{13}$. Talvez ele tenha sido considerado o maior expoente do pensamento jesuítico, entre outros motivos, porque

pues, sin que éstos pudiesen impedirlo, el arbitrio podría inclinarse en sentido contrario -, sino que procedería de la ciencia media, por medio de la cual Dios conoce, con anterioridad a todo acto de su voluntad".

${ }^{11}$ Para a polêmica, ver: FERRARO, 1995 e HEREDIA, 1968.

12 Apesar das visões tendenciosas, pode-se organizar a difícil cronologia reformada nas seguintes obras: GRATH, 2007; e SPROUL, 2001.

13 Francisco Suárez chegou a escrever "En defensa de la Compañia acerca del libre albedrio" (HERENDIA, 1968, p. 418-426). 
procurou dar uma resposta a cada uma delas ${ }^{14}$. Por um lado, foi visto como um grande conciliador das dissidências das principais ordens católicas. Ainda, forneceu uma nova interpretação sobre a teologia e filosofia de seu tempo, posicionando-se e servindo de referência para grandes nomes do pensamento ocidental.

Não por acaso, seus intérpretes referem-no como um personagem de transição entre o medieval e o moderno. Seu brilho intelectual alcançou a mais alta corte temporal e espiritual. Seu relacionamento constante com Felipe II e os papas Paulo V e Gregório XVI esclarece porque ele se tornou o maior nome da teologia da contrarreforma ${ }^{15}$ e o grande artífice da segunda geração tomista, sucedendo Francisco de Vitória. Em outras palavras, Suárez funcionou como um general na grande batalha teológica dos seiscentos. Organizando as ordens de seu campo de guerra de forma diplomática, criou novas armas conceituais para concentrar esforços contra os verdadeiros inimigos da ortodoxia católica: Lutero e a recém-convertida Inglaterra de Jaime $\mathrm{I}^{16}$.

\section{A ignorância invencível de Deus}

O problema da ignorância invencível foi uma das muitas frentes de batalha em que Francisco Suárez esteve envolvido. A incidência deste tema em Suárez normalmente acompanha o debate sobre a possibilidade do homem poder fazer o bem mesmo que ele não conheça a Deus. Talvez por sua sinuosidade, ainda não exista estudo específico sobre o conceito. Sem pretender esgotar a sua riqueza, cujos limites extrapolam nossa circunscrição, vamos perpassar panoramicamente o vasto conjunto de seus escritos a fim de apresentar o conceito de ignorância de Deus e da lei natural. Em De voluntario et involuntario ${ }^{17}$, em definição muito próxima a tomista, ele define que uma ignorância é chamada invencível quando não se pode fazer nada para extirpá-la ${ }^{18}$.

Suárez, porém, foi além de Tomás de Aquino ao dividir a ignorância invencível em dois tipos: o primeiro tipo seria quando o indivíduo falha no discernimento de uma

\footnotetext{
${ }^{14}$ Um ótimo panorama deste debate pode ser lido em Sienra (1999, p. 265-278). Além disso, ver: LÓPEZ, 2006, p. 3-38; CUADRADO, 1999, 59-78.

15 Para o problema da contrarreforma, em abordagem mais geral, ver: MULLET, 1985; em Suárez: MACEIRAS, 1998, pp. 59-63; em Portugal: TORGAL, 1981, 2 vol. E recente: PALOMO, 2006.

16 Embora toda a obra de Francisco Suárez tenha se dirigido contra as teses protestantes, é preciso destacar que este movimento é mais evidente em De Gratia (1651) e De Defensio Fidei Catholicae adversus Anglicanae sectae errores (1613).

17 Obra póstuma, publicada em Lyon em 1620, recolhidas de suas lições ditadas entre 1606 e 1609. Informações em Gonçalo Moita, “Anexos”, in: SUÁREZ, 2004, p. 158.

18 Consultar: "et ideo dicendum cum communi sententia ignorantiam invincibilem illam esse, in qua homo voluntarie nihil facere omittit eorum, quae potest et debet facere ad illam expellendam, et nihilominus eam expellere non potest.” disp. IV, sect. i, 19, apud LAEMERS, 2011, p. 215.
} 
obrigação particular, como por exemplo, quando alguém não dispõe de informação necessária para cumprir rigorosamente uma lei; o segundo tipo, nomeado de "ignorância provável", era aplicada em um contexto em que indivíduos, apesar de seu imenso esforço $^{19}$, estariam inabilitados para resolver certas dúvidas morais acerca da melhor maneira de agir. Nesse sentido, a ignorância torna-se um dos principais motivos da dúvida moral, geradora da incerteza, seja no plano da consciência intrínseca (consciência) ou da consciência extrínseca (ato) (MARYS, 2008, p. 123-124). Há de se destacar que esta interpretação é inovadora frente à teologia moral tomista e tornar-se-á parte integrante da tradição probabilista ${ }^{20}$.

Uma vez definidos os dois tipos de ignorância invencível para Suárez, é chegada a hora de examinar os limites da primeira das ignorâncias: de Deus. Do ponto de vista de Agostinho, não se poderia aplicar a ignorância invencível de Deus sob o argumento de que aqueles que o desconhecem poderiam ter tido acesso a Ele por si mesmos. O bispo de Hipona baseava-se numa passagem de Paulo de Tarso na Carta aos Romanos, em que o apóstolo declara: "o que se pode conhecer de Deus é manifesto entre eles, pois Deus lho revelou. Sua realidade invisível - seu eterno poder e sua divindade - tornou-se inteligível, desde a criação do mundo, através das criaturas, de sorte que não têm desculpa"21. Na interpretação exegética de Agostinho, aqueles que desconhecem Deus seriam ignorantes por culpa própria. Nessa condição, estariam literalmente desgraçados, haja visto não poderiam fazer nenhum tipo de bem apenas por si mesmos.

A perspectiva de Tomás de Aquino era distinta. Para ele, seria preciso diferenciar infiéis, hereges e apóstatas, classificando os primeiros como aqueles que não tiveram oportunidade para conhecer um pregador $^{22}$ e não por sua própria culpa. Assim, aqueles que desconheciam a Deus não poderiam ser condenados porque eram ignorantes invencíveis. Desse modo, “os que assim são infiéis condenam-se, certamente, por causa de outros pecados, que não podem ser perdoados sem a fé; não, porém, pelo de infidelidade" (AQUINO, 2001, p. 153).

\footnotetext{
19 Quando Francisco Suárez trata do problema deste "esforço", ele se refere aqui ao problema da consciência moral em foro interno. Sobre este problema, ver PROSPERI, 2014; DELUMEAU, 1998 e PRODI, 2005.

${ }^{20}$ Sobre o probabilismo em geral e a influência de Suárez em sua consolidação, ver: TUTINO, 2017; SCHÜSSLER, R., 2005, p. 91-114.

${ }^{21} \mathrm{Rm}$ 1, 18-23 apud Agostinho, Spirito et Littera (Sobre o Espírito e a Lei), in: AGOSTINHO, Santo. A graça, I, Tr. A. Belmonte. Patrística, 12. São Paulo, Paulus, 1998, p. 38.

22 "Se, porém, se entende infidelidade no sentido de negação pura, como no caso daqueles que jamais ouviram falar das verdades da fé, não tem razão de pecado, mas de pena, porque tal ignorância das coisas divinas é consequência do pecado do primeiro pai." (AQUINO, Tomas de. Suma, II, II, Q. 10, a. 1, p. 153).
} 
A partir deste importante fundamento tomista, Suárez diferencia três tipos de infiéis na disputa XII em De Gratia. O primeiro grupo foi classificado como infiéis positivos, isto é, "aqueles que não tem desculpa"23. Dentro deste tipo estavam os que ouviram a fé e a recusaram ou, pior, aqueles que aceitaram a fé inicialmente e depois a abandonaram (apóstatas). O segundo grupo faz parte daqueles que nunca ouviram nada acerca da palavra, contemplados pela categoria de infidelidade negativa. Finalmente, o terceiro grupo fala daqueles que ouviram algo sobre a palavra, mas não o suficiente ${ }^{24}$.

O primeiro grupo não poderia ser considerado, em hipótese alguma, ignorante invencível. Para fundamentar porque o segundo e o terceiro grupo poderiam enquadrarse nesta categoria, Suárez aponta três motivos. Primeiro porque se a aceitação do cristianismo deve ser um ato voluntário, a recusa também haveria de ser. Assim, ainda que isso não implique necessariamente em sua salvação, Suárez defende que os ignorantes não poderiam ser culpabilizados quando nunca ouviram falar da fé. Nota-se que nesta altura ele refere-se explicitamente aos ameríndios.

Em segundo lugar, sustenta que o desconhecimento de Deus não é um pecado em si mesmo ${ }^{25}$, mas um impedimento da virtude. Reafirmando a posição de Tomás de Aquino, Suárez afirma que tais homens podem fazer alguns bens particulares, embora não universais ou finais. Dessa forma, em De triplici virtute theologica ${ }^{26}$, o jesuíta defende que os que estão no segundo grupo podem estar contemplados no principia de ignorantia inculpabili diante de Deus. Inclusive, diga-se de passagem, na sequência do mesmo livro, Suarez escreve sobre a possibilidade de se fazer ou não guerra com os infiéis, adotando uma postura muito similar a de Francisco de Vitória ${ }^{27}$.

Contudo, o filósofo jesuíta foi além de Vitória ao fundamentar teologicamente a possibilidade dos infiéis, que nunca ouviram a palavra de Deus, se salvarem. Como demonstramos anteriormente, contudo, havia dois grandes obstáculos para isso: o primeiro era o de que não se poderia ser salvo sem a graça seguindo apenas a lei natural;

\footnotetext{
23 "nullam enim habent excusationem" (FASTIGGI, 2018, p. 266).

${ }^{24}$ Ao contrário do que se poderia pensar, não se trata dos povos indígenas desconhecedores da palavra, mas sobretudo nos indianos e sarracenos.

25 Nessa altura, ele opõe-se à tese do nominalista Gregório Rimini (1300-1358), mas esta posição agostiniana revela uma grande diferença entre as visões antropológicas de cada um dos autores.

${ }^{26}$ Sobretudo no tract. 1, disp. XII, sect.. IV, 1-3. Este tratado foi publicado em momento posterior à morte de Suárez, em Coimbra em 1621, trabalhando pela primeira vez em Roma sobre tais questões (1583-84) para depois, já como professor em Coimbra no final de sua vida (1614-1615), com o auxílio de seu aluno Dom André de Almada. Ver: MOITA, Gonçalo, in: SUÁREZ, 2004, p. 160.

${ }^{27}$ Francisco de Vitória defendeu que não se poderia mover a guerra justa contra os índios - entre outros motivos - em função de sua condição de ignorantes invencíveis. Para este problema, ver: MOTA, 2019. Este problema é tratado sobretudo na Disputa XVIII, recentemente traduzida para o inglês. Ver: PINK, 2015.
} 
o segundo resume-se ao princípio "fora da Igreja não há salvação", negando a salvação para aqueles que não conhecem Cristo e o Evangelho. Para contrapor-se a tais apontamentos, são evocados cinco argumentos complexos para defender, de um lado, que os que desconhecem Deus podem ser salvos e, por outro, que eles têm força suficiente para - sozinhos -, cumprirem a lei natural.

No primeiro, Suárez explica que é da vontade de Deus que todos se salvem (Deus vult omnes homines salvos fieri). Segundo ele, supor que aqueles que não ouviram a palavra não poderiam se salvar aproximá-los-ia da heresia de que os índios não possuíam alma, defendida por Juan Inés Sepúlveda. Contudo, restava ainda responder como os índios poderiam ser salvos. Ora, o único meio pelo qual Deus pode prover a salvação seria a graça. De acordo com a tradição paulina, confirmada pelo Concílio de Trento, a graça só pode ser obtida pelo batismo e pela fé explícita. Para resolver tais argumentos, Francisco Suárez defendeu a existência de uma graça que poderia infundir o coração dos homens em direção ao bem apenas pela fé: "a pura graça”, resultante direta da vontade de Deus para salvar a todos. Para recebê-la seria necessário a fé explícita ${ }^{28}$. Suárez propõe, contudo, uma nova subdivisão: haveria uma fé explícita real (in re) e virtual (in voto) (LAEMERS, 2011, p. 334). O exemplo fornecido por ele é o do batismo: ainda que não fosse possível realizá-lo, para receber a graça seria necessário ao menos o desejo implícito de recebê-lo, do contrário não haveria graça e sem a graça não há salvação ${ }^{29}$.

Em segundo lugar, havia ainda outra grande dificuldade a ser considerada e superada: o princípio do Extra ecclesiam nulla salus. Suárez não nega este princípio, mas, a partir de um argumento de Roberto Bellarmino, sai em defesa de uma igreja real e outra in voto. Em outras palavras, segundo o seu argumento, aqueles que possuíssem a fé explícita in voto pertenciam a uma igreja invisível in voto. Dentro da fé explícita in voto estariam detentores do desejo de batismo, sendo possível, portanto, o recebimento da graça e, por conseguinte, a salvação ${ }^{30}$. Nesse sentido, a única igreja na qual os

\footnotetext{
${ }^{28}$ Em sua exposição, Francisco Suárez esclarece que há autores que defendem a existência de uma fé implícita, mas que tal proposição feriria as escrituras e as proposições do Concílio de Trento. Por isso defendeu que deveria haver a fé explícita. Suas interlocuções sobre este tema estão na disputa IV sobre a fé suficiente, seção III, em De triplici virtute theologica, in: Opera Omnia, Paris: Ludovicum Vivès, 1858 , p. 125-131.

${ }^{29}$ Sobre as reflexões acerca do batismo e da salvação, ver: PROSPERI, 1999. Para o problema do batismo na missionação do império português, ver: MARCOCCI, 2012; e MOTA, 2016.

30 Nota-se a singularidade deste argumento, pois por um lado ele ajudava a justificar o desejo de batismo, previsto no Concílio de Trento, mas por outro assemelhava-se ao argumento luterano que Suárez evidentemente haveria de ter um grande cuidado de não se aproximar.
} 
ignorantes poderiam entrar e a única fé que poderiam alcançar seria in voto, condição suficiente para a salvação. Ao sugerir que todos podem ser salvos através da fé explícita in voto e da graça pura, Francisco Suarez está influenciado pela ciência média molinista, pois supõe que Deus quer que todos se salvem e sejam auxiliados pela graça por aqueles que ele antevê que farão um bom uso dela.

Em seu terceiro argumento, Francisco Suárez pergunta-se: aqueles que desconhecem Deus podem praticar o bem honesto? Nesta disputa, o jesuíta trabalha simultaneamente com os limites do ignorante, por um lado, e a possibilidade do homem fazer algum bem utilizando apenas seu livre-arbítrio, por outro:

el bien honesto es de suyo amable y basta para la honestidad del acto, aunque no se piense en Dios ni antes se haya pensado de tal manera, que el pasado amor de Dios influya ahora de algún modo en el acto. Además: una cosa es amar algo como a sumo bien, y outra amar algo como bien de suyo amable. Lo primeiro es próprio de Dios; mas, lo segundo es comunicado por el mismo Dios a todo bien honesto (...) no es mado como último fin, sino que tal amor tiende por su naturaleza a Dios; y esto es suficiente para que no se diga que el hombre goza de tal bien, sino que usa de é; mas, entonces se diría que goza de él cuando constituye em él su último fin, y esto es lo que dice San Augustín que es ser soberbo (SUÁREZ, 1918-1921, p. 148-149)

Assim, para realizar o sumo bem, seria necessário o amor infinito de Deus. Mas sem ele, este bem continua pertencendo a Deus e sua bondade seria suficiente para que o homem usufrua de tal bem com vistas à salvação. O jesuíta parece ter muita consciência deste movimento exegético ousado, pois na sequência anunciou que para a defesa de suas teses "ni la autoridad de San Agustin es obstáculo" (Ibidem).

Em seu quarto argumento, pergunta-se: seria possível cumprir a lei natural sem a caridade infusa ${ }^{31}$, isto é, sem a graça? Sua resposta dirigiu-se diretamente aos luteranos e calvinistas e indiretamente aos dominicanos ${ }^{32}$, ao dizer do livre-arbítrio do homem para a remissão completa dos pecados. Em seguida, defende que pode haver alguma caridade no homem, mesmo quando ele está em pecado. Por fim, sustenta que a lei natural não se conecta necessariamente com a graça, o que permite ao homem sem Deus possa fazer o bem por si mesmo. Dessa forma, a defesa de que os índios podem ser salvos em estado de ignorância invencível de Deus se sustenta a partir de quatro

\footnotetext{
31 "Se podría dudar, si, supuesta a elevación del hombre a un fin sobrenatural, es necessaria esta circunstancia para cumplir sin pecado la misma ley natural” (SUÁREZ, 1918-1921, p. 151).

32 "y en este sentido es erónea y condenada virtualmente em los luteranos por el Concilio de Trento, sesión 6, canon 7. Pues, según aquella sentencia, todas las obras hechas fuera del estado de gracia son contra precepto divino y pecados" (SUÁREZ, 1918-1921, p. 150).
} 
movimentos argumentativos: seria suficiente a fé explícita in voto, o pertencimento a uma igreja invisível in voto, a possibilidade dos ignorantes de Deus fazerem o bem por si mesmos e o cumprimento da lei natural mesmo sem o recebimento da graça.

\section{A lei natural}

Apesar de considerar que os índios poderiam ser salvos na condição de ignorantes, o maior representante da segunda geração tomista jamais aceitou que eles poderiam sê-lo sem o cumprimento da lei natural. Aos nossos olhos contemporâneos, parece-nos absurda a possibilidade de Suárez aceitar a salvação daqueles que ignoram Deus, mas não os que ignoram a lei natural. Mas afinal, o que ele entendia por lei natural? Quais são os seus princípios que podem ser ignorados? Deus pode dispensar as leis Naturais? Quais são os limites de atuação dos selvagens frente a lei natural? Uma vez descumpridas, quais seriam suas penalidades?

No momento em que Suárez escreveu, havia uma grande divisão interpretativa acerca da Lei em geral. Na perspectiva aristotélico-tomista, a Lei era definida pela Razão de Deus. Do ponto de vista agostiniano-nominalista, a Lei era fundamentada a partir da vontade de Deus. Embora estivesse inclinado para a primeira visão, para Francisco Suárez "para produzir a lei são necessários actos do intelecto e da vontade" (SUÁREZ, 2004, p. 222-223). Segundo ele, o ato da vontade associa-se à lei porque possui a intenção do bem comum, por um lado, e tem poder para obrigar os súditos, por outro. Já o ato da razão ilumina, ordena e governa. Assim,

a primeira coisa que se pode perceber na vontade do legislador é a intenção do bem comum, ou o bem de governar os súditos, em virtude da qual se segue imediatamente no intelecto a consideração desta ou daquela lei, de tal modo que seja justa ou conveniente à república; esses dois atos, no homem, entendem-se sucessiva e discursivamente [...] em poucas palavras, a lei não somente ilumina, mas também move e impele" (SUÁREZ, 2004, p. 223)

Nessas condições, se esclarece porque o tratado de Suárez é intitulado Deo Legilatore, pois ele o entende como um legislador que moveu o intelecto e a vontade para construir um "preceito geral, justo e estável, suficientemente promulgado" 33 . Esta

\footnotetext{
${ }^{33}$ SUÁREZ, 2004, p. 223, cap. XII, p. 332. É importante dizer que a definição de ius se aproxima muito da de Lei: "certa faculdade moral eu cada um tem em relação ao que é seu" (SUÁREZ, 2004, p. 196). Michel Villey explica que desde Vitória se ressaltou o valor do direito natural associado à lei para "fazer abstração de Deus nas ciências do direito". Ele interpreta este movimento como uma tentativa de fazer frente aos movimentos protestantes, por um lado, e reafirmar o livre-arbítrio por outro, tornando-se uma concepção um lugar comum em toda a escolástica jusnaturalista, que teve em Suárez a sua maior expressão (VILLEY, 2009, p. 372-373).
} 
mesma lei, porém, há de ser compreendida num triplo estado: na mente do legislador, nos súditos (ius) e em algum sinal externo a eles ${ }^{34}$, como na letra da lei ou na vontade de um superior (legislação positiva). Acrescenta ainda que não há nenhuma criatura racional que não esteja submetida a alguma lei ${ }^{35}$, lembrando a célebre passagem aristotélica de que "o homem, recebida a sua perfeição, é o melhor de todos os animais, do mesmo modo, se se afastar da lei e da justiça, é o pior de todos" (SUÁREZ, 2004, p. 216).

Entendidas estas definições básicas, cabe expor brevemente a diferença entre os tipos de lei, divididas em três: eterna, natural e humana. A lei eterna existe em Deus. Sua utilidade não consiste em ordenar a si mesma para um fim, mas "ordenar todas as coisas para os seus próprios fins" (SUÁREZ, 2004, p. 207). Sendo Deus, portanto, fonte da Lei eterna, é preciso supor que a eternidade só existe em Deus. Todavia, há muitas leis que estão fora de Deus. Por isso elas são chamadas temporais. Entres estas, têm-se a divisão entre a natural e humana ${ }^{36}$.

Se a lei eterna rege todas as coisas, por sua vez a lei natural é a "participação daquela razão impressa nas criaturas, para que tendam para os seus destinados fins" ou a “participação da lei eterna na criatura racional” (SUÁREZ, 2004, p. 209). Em outras palavras, o espaço invisível em que o criador ordena a criatura e participa da ordem divina é a lei natural. Esta, por sua vez, deve vir antes da humana, pois se distingue daquela na medida em que não foi criada pelo homem, mas está presente nele. A Lei natural situa-se na fronteira entre o aquém de Deus e além do homem. A lei natural está de tal maneira subjacente à criatura racional que Suárez também a define como "um juízo natural da razão humana [...] a lei de Deus, ao chegar, inflamando a nossa mente, atrai-a para si e excita a nossa consciência, e por isso se diz que é a própria lei na nossa mente" (SUÁREZ, 2004, p. 222). Assim, é a lei que ignora o crescimento e desconhece a infância; e então vive e manda quando começa a inteligência (SUÁREZ, 1918-1921, Livro I, p. 62). Portanto, há uma divisão entre a lei eterna e a lei natural, pois Deus a

\footnotetext{
34 "[...] matéria exterior, como na letra da lei, ou na voz que se manifesta a vontade do superior" (SUÁREZ, 2004, p. 221). Nesse caso, trata-se na lei positiva, que pode ser eterna, humana e legal.

35 “[...] alguma lei é, de algum modo, absolutamente necessária para que possa viver de acordo com sua própria natureza" (SUÁREZ, 2004, p. 205).

${ }^{36}$ Esta distinção e o debate em torno do jusnaturalismo de Suárez em seu tempo pode ser estudado em: ÅKERLUND, Erik "Suárez's Ideas on Natural Law in the Light of His Philosophical Anthropology and Moral Psychology", in: The Nature of Rights: Moral and Political Aspects of Rights in Late Medieval and Early Modern Philosophy, ed. Virpi Mäkinen (Acta Philosphica Fennica [Vol. 87], Helsinki, 2010, 165196.
} 
criou, mas sua razão independe Dele no ser humano: ela é intrínseca e tem força para mandar, portanto estamos obrigados a ela.

Além disso, a Lei natural deve ser entendida duplamente, a partir da Razão e da Graça: a primeira caracterizada por uma natureza pura, proveniente da luz da razão natural; a segunda, uma natureza sobrenatural, advinda da luz divina por meio da fé. Francisco Suárez resume a dupla natureza e sua ação da seguinte forma:

a primeira provém de Deus por meio da natureza, da qual brota como propriedade desta; a segunda, por outro lado, provém de Deus, que por si mesmo infunde a graça e a própria luz sobrenatural e que também dirige activamente os homens para o cumprimento desta Lei (SUÁREZ, 2004, p. 211).

Com efeito, sua concepção de Lei natural é complexa, já que sintetiza num só conceito a dimensão da natureza e da graça. Como em Agostinho ou Tomás de Aquino, a luz natural permite que o homem conheça as leis naturais e a Deus pelo intelecto, mas apenas a graça pelo coração permite que ele a cumpra. Ao definir a Lei natural dessa maneira, Francisco Suarez busca responder a três problemas teológicos de seu tempo: primeiro, reforçar o posicionamento tomista de que o cumprimento da Lei natural é imprescindível $^{37}$; segundo, reforçar o argumento contra os luteranos de que somente a graça era suficiente para a salvação; terceiro, buscar resolver o problema da graça e do livre-arbítrio apresentado anteriormente, no seio da Polémica de Auxiliis.

\section{A ignorância da Lei natural}

Após a definição de lei natural, Francisco Suárez se pergunta se é possível ignorá-la. Segundo ele, apesar de a lei natural ser apenas uma, ela possui três ordens distintas. Em sua argumentação, uma vez que todos os homens possuem intelecto, eles conhecem em substância a lei natural, mas não sua forma completa. Por isso, segundo ele, pode haver ignorância de partes da lei natural, mas não dela por inteiro. Para explicar os "níveis de ignorância" diante da lei natural, Suarez divide-a em três partes: a primeira ordem seria não cometer o mal, comunidade de certos bens e liberdade dos homens; a segunda ordem diz respeito aos princípios imediatos que se deduzem do primeiro princípio, incluindo aí o decálogo; a terceira e última ordem, por fim, diz respeito às regras que são deduzidas dos dois princípios anteriores, mas que necessitam de algum discurso para serem suficientemente conhecidas. Aí se incluem o

\footnotetext{
${ }^{37}$ LEIJENHORST, 2007, p. 237-262.
} 
cumprimento de pactos e promessas políticas, piedade com os padres, amor ao próximo, entre outros aspectos ${ }^{38}$.

Os primeiros princípios são impossíveis de serem ignorados. Os da segunda e da terceira ordem, contudo, apesar de serem facilmente observáveis, podem ser desconhecidos por possuírem alguma demanda de diligência e procura. Contudo, Suárez esclarece que esta ignorância pode acontecer apenas por um breve tempo e em pouquíssimos casos. Além disso, tal ignorância não pode ser considerada invencível, já que esses princípios podem ser facilmente descobertos e cumpridos. Em outras palavras, para Suárez é possível cumprir o Decálogo, mesmo sem o conhecer.

Para explicar teologicamente porque não há ignorância invencível dos primeiros princípios, Suárez teve que responder a uma pergunta frequente no seu período: Deus pode dispensar os homens dos preceitos naturais? Segundo ele, embora ele tenha tal poder, "no dispensa Dios en algún precepto natural, sino que muda su matéria o circunstancias" (SUÁREZ, 2004, p. 227).

No intuito de estabelecer melhor tais circunstâncias, Suárez levanta três disputas concernentes aos infiéis americanos. Na primeira, ele se pergunta se a lei natural pode ser apagada da mente de alguém. Ele nega veementemente, defendendo que ainda que haja infiéis errantes, sem nenhum tipo de ordenação, com base em algum preceito, não seria possível que ao menos em alguns homens fosse notado algum tipo de manifestação da luz natural. Na sequência, ele deixa claro seu apontamento: nenhum preceito natural é apagado totalmente nem mesmo por ignorância (SUÁREZ, 2004, p. 174), pois o erro ou o desconhecimento não apaga a lei em si, mas oculta o que já se sabe, o que seria muito distinto. Neste sentido, evoca o argumento aristotélico-tomista ao mostrar que a ignorância não é um pecado em si mesmo, mas antes um impedimento da virtude.

$\mathrm{Na}$ segunda disputa ele se pergunta se a Lei natural também não existe nos homens brutos ${ }^{39}$. Diferente do direito das gentes ${ }^{40}$, a lei natural não obriga os homens, por meio de decretos ou leis formais, antes impõe-se às obras materiais, as quais, por

\footnotetext{
${ }^{38}$ Michel Villey observa aqui um distanciamento de Francisco Suárez em relação à concepção de Tomás de Aquino, que entende a Lei natural a partir da observação da pólis e dos grupos humanos. Já Suárez, neste ponto, se aproxima da concepção estoica segundo a qual o direito natural está subjacente ao intelecto humano. Isso permite compreender, por exemplo, porque o direito natural está associado à toda a criatura racional, mesmo aos infiéis (VILLEY, 2009, p. 414-415).

${ }^{39}$ Este conceito é complexo e pode referir-se a muitos objetos. Neste contexto, contudo, Suárez parece dirigir-se aos índios. Para um exame da complexidade deste vocabulário, ver: HESPANHA, 2010.

${ }^{40}$ Francisco Suárez explica que o direito das gentes se diferencia do natural porque este é intrínseco, ao passo que aquele é extrínseco; o natural é necessário, no das gentes há algum arbítrio humano. O natural é comum até mesmo aos animais, embora estes não tenham consciência disso, ao passo que o outro se restringe aos homens. Ver: SUÁREZ, 1918-1921, p. 254.
} 
sua vez, estão contempladas na natureza humana. Ele fornece uma série de exemplos, tais como a união macho e fêmea, canibalismo, entre outros. $\mathrm{Na}$ terceira, trata da promulgação da lei natural. A partir do princípio de que uma lei só obriga a partir de sua promulgação, Francisco Suarez busca estabelecer a diferença entre a publicação da lei natural e das outras leis. Sendo a lei natural dupla, advinda da luz natural e da graça, sua promulgação é imediata, ocorrendo de dois modos: pela razão, enquanto "voz comum de toda a natureza, ou antes de seu autor" (SUÁREZ, 2004, p. 324); e pela graça, "porque Deus está por si mesmo disposto a infundir e promulgar a luz da fé, por meio da qual ela se manifesta" (Ibidem. Portanto, na mesma linha de Francisco de Vitória, ele explica que, a partir do primeiro uso da razão, a lei natural já está promulgada.

A consumação da Lei humana, em contraste, demanda tempo. Para o jesuíta, todos precisam deter seu conhecimento para ela ser obrigatória, sendo impossível que o conhecimento desta lei se espalhe rapidamente. Assim, supondo que um príncipe ou mesmo o papa obrigue os infiéis sem lhes dar os meios para cumprir a Lei, eles estariam extrapolando sua potestade e até mesmo o limite da lei.

Consequentemente, seria necessário que as leis fossem suficientemente promulgadas num determinado tempo, do contrário, os índios estariam em condição de ignorância invencível. Em síntese, "puede decirse que 1 ley obliga a los ignorantes en cuanto a la suficiencia, mas no em cuanto a la eficiencia" (SUÀREZ, 1918-1921, p. 257). Nessa medida, tal como Francisco de Vitória, Suarez não crê que os infiéis ignorantes da Lei humana devem ser condenados mortalmente, apenas venialmente, a não ser eu a descumpram depois de sua consumação.

\section{As penalidades da Lei}

Não pode se afirmar o mesmo das penalidades concernentes à lei natual. Suárez enfatizou suas definições de que a lei natural é a lei de Deus, por isso define-se também pela graça. Os que a desobedecem, destarte, possuem culpa mortal e venial, no foro interno e externo, acrescenta ele. Além disso, amparado pelo concílio de Trento, capítulo XI, cânones 18-20, declarou que mesmo Adão e Eva já estavam sujeitos à Lei natural (SUÁREZ, 2004, p. 270).

Restava, contudo, responder ao argumento contrário, isto é, se era possível ser salvo apenas cumprindo a lei natural, epicentro da polêmica pelagiana. Para defender a impossibilidade, procurou mostrar que a lei natural, em sua dupla condição de conatural 
e sobrenatural, teve sua origem na revelação divina (pela graça), mas depois foi passada de geração em geração pelos povos. Segundo ele:

Tal como nunca faltou no universo, naquilo que dependeu de Deus, uma manifestação suficiente da fé, do mesmo modo nunca faltou uma promulgação suficiente daquela lei. O modo de promulgação, por outro lado, foi como que conatural daquela lei, de tal maneira que passou pela revelação divina; depois, na verdade passou de pais para filhos por meio da tradição, ao mesmo tempo que Deus previa e colaborava em cada um para que percebesse a iluminação divina daquela lei (SUÁREZ, 2004, p. 324).

A partir desses apontamentos, Suarez argumentava que, uma vez seguidos os ensinamentos herdados pela tradição, cumpria-se a lei natural. Na sequência, de maneira semelhante à argumentação anterior, diferencia dois tipos de infiéis que podem ser salvos: aqueles que se batizam concretamente (in re), compondo o número da Igreja e os que podem ser batizados in voto, de modo que estão "en la Iglesia, mas por mérito, no por número".

$* * *$

A estratégia argumentativa de Francisco Suarez em torno do problema da ignorância invencível, como parece evidente, moveu-se em constantes de conciliação e combate, característico de seu posto na contrarreforma e na grande guerra teológica dos seiscentos. No tocante aos ignorantes de Deus, Suárez diferenciou os infiéis hereges, apóstatas e ignorantes, contemplados pela categoria de infidelidade negativa. Para fundamentar que tais ignorantes poderiam ser salvos, determinou que era necessária a fé explícita em Deus, sendo possível, todavia, que ela fosse devotada in re e in voto.

Aqueles que possuíam a fé in voto, por sua vez, pertenciam à igreja in voto, sendo possível ser virtuoso e praticar o sumo bem ainda que sem ciência dele. Tais condições, por fim, permitem que esta categoria de infiéis cumpra a lei natural. Através de sua interpretação tomista, portanto, Suárez buscou uma resposta conciliadora entre católicos, de um lado, e combativa frente aos protestantes, de outro.

Em todas as faces de sua argumentação, contudo, Suárez foi veemente ao afirmar que seria impossível desconhecer inteiramente a lei natural em função da participação humana e divina na mesma, exceto poucas regras derivadas do decálogo. Nem mesmo Deus poderia dispensá-la e em nenhuma hipótese ela poderia ser apagada da mente de alguém, já que sua promulgação é concomitante à própria razão em nosso intelecto. Por outro lado, Suárez defende que qualquer um poderia cumprir a lei natural, 
mesmo na ignorância de Deus. Tais indivíduos, além disso, poderiam obter a salvação, desde que fossem incluídos no que ele chama de batismo in voto.

A recepção das ideias de Suárez tornou-se o cume do pensamento teológico jesuítico. Ademais, se também na história das ideias os espanhóis conheceram o siglo de oro, não parece exagero dizer que o pensamento de Suárez era uma de suas mais valiosas minas. Ademais, foi diretamente influenciado pelo filósofo Bartolomé de Medina, precursor do probabilismo, em várias escalas de sua defesa, tais como: no argumento da graça suficiente e da graça pura; seus posicionamentos frente à fé explícita, igreja e batismo in voto; a posição de que as ações devem ser sempre julgadas a partir das circunstâncias; e, sobretudo, a possibilidade da ignorância poder ser invencível tanto pela falta desconhecimento de Deus quanto pela dúvida do agente sobre qual seria a melhor maneira de agir, abrindo espaço para o argumento de que qualquer ação poderia ser justificada e, nessa medida, perdoada.

Suas proposições, contudo, foram questionadas, trabalhadas e reinterpretadas por grandes figuras do século XVII. De um lado, suas teses foram utilizadas pelos nomes mais brilhante da escolástica, como Cardeal de Lugo, Rodrigo Arriagha, Escobar e outros autores inseridos na tradição probabilista ${ }^{41}$. De outro, foi criticado posteriormente pelos jansenistas, em especial Blasise Pascal e Antoine Arnauld, no último quartel do século XVII, período em que o debate sobre a ignorância invencível dentro dos debates sobre os pecados da ignorância ${ }^{42}$.

Pode-se afirmar que o conceito de ignorância invencível, no tempo de Tomás de Aquino, fora apenas mais uma de suas categorias em sua vasta Suma Teológica. Contudo, após o período das grandes navegações, ela ganha uma importância extraordinária na medida em que poderia ser atribuída à maior parte da humanidade, visto que a maior parte dos povos contados não conhecia Deus e a palavra Cristã. Francisco de Vitória foi um dos pioneiros ao articular tal conceito para os não-europeus. Em seus argumentos, buscou compreender quais os limites daqueles que ignoram Deus e a lei natural, quando se inicia a sua responsabilidade sobre este desconhecimento e quais são os limites de atuação da Coroa, do papado e da teologia moral frente aos índios americanos. Embora Francisco Suárez concorde com diversos aspectos do pensamento de Vitória, ele buscou fundamentar teológica e filosoficamente os limites

41 Para o desdobramento do debate sobre o conceito de Deus após Suárez, ver: DOYLE, 2012; AGOSTINI, 2008; LEGAZ, 1947, 212-296; CEÑAL, 1970.

${ }^{42}$ Sobre a crítica dos Jansenistas em torno da ignorância invencível defendida pelos jesuítas, incluindo a perspectiva de Suárez, ver: GAY, 2018; e CARDOSO, 2000. 
desta ignorância em meio à grande guerra teológica do século XVI. Em meio aos posicionamentos protestantes, nominalistas-franciscanos e dominicanos, aceitando a possibilidade de os índios serem salvos sem conhecer Deus, mas cumprindo a lei natural.

Embora nem sempre Suárez explicite os problemas em torno da salvação dos índios, seu posicionamento diante da ignorância invencível exerceu forte impacto na América ibérica, em especial na a atuação missionária sobre os índios ${ }^{43}$. Dos missionários e teólogos que escreveram americanos que foram influenciados por seu pensamento sobre a ignorância invencível, podem ser citados, entre outros, Diego de Avendaño, Alonso de La Peña, Simão de Vasconcelos e Antônio Vieira. Tais autores buscaram explorar os limites do conceito de ignorância invencível dos índios para tentar superar seu próprio desconhecimento sobre eles.

\section{Referências}

AGOSTINHO, Sant, A graça, I, Tr. A. Belmonte, São Paulo, Paulus, 1998.

AGOSTINI, Igor. L'infinità di Dio, Il dibattito da Suárez a Caterus (1597-1641). Roma: Editori Riuniti, 2008.

ÅKERLUND, Erik "Suárez's Ideas on Natural Law in the Light of His Philosophical Anthropology and Moral Psychology". In: MAKINEN, Virpi. The Nature of Rights: Moral and Political Aspects of Rights in Late Medieval and Early Modern Philosophy. v. 87. Helsinki, 2010, 165-196.

AQUINO, Tomás de. Suma Teológica - ed. bilíngue, C, J. Pinto de Oliveira (org.), São Paulo, Loyola, 2001.

BAÑEZ, Domingo Apología de los hermanos dominicos contra la concordia de Luís de Molina. Oviedo: Pentalfa, 2002.

BONET, Alberto. La filosofía de la libertad en las controversias teológicas del siglo XVI y primera mitad del XVII. Barcelona: Subirana, 1932.

CARDOSO, Adelino. Uma nova heresia à medida de um novo mundo: a ofensiva de Arnauld contra a doutrina do pecado filosófico. Philosophica, Lisboa, n. 15, 2000, p. 117-133.

\footnotetext{
${ }^{43}$ Ver a conferência de Roberto Hofmeister Pich, "Francisco Suárez na escolástica latino-americana", in: A conferência foi apresentada na manhã de 28-09-2017, dia de encerramento do VIII Colóquio Internacional IHU e XX Colóquio Filosofia UNISINOS - Metafísica e Filosofia Prática. A atualidade do pensamento de Francisco Suárez, 400 anos depois, dia 28/09/2017, RUIZ, 2015 e CASARIN, 2018.
} 
CASARIN, Régis Franco. Disputa do probabilismo na América colonial. Tese (Doutorado em Filosofia). Universidade do Vale dos Sinos (UNISINOS). São Leopoldo, 2018.

CEÑAL, Ramón. "El argumento ontológico de la existencia de Dios en la escolástica de los siglos XVII y XVIII". In: Homenaje a Xavier Zubiri. Madrid: Editorial Moneda y Credito, 1970.

CROSS, Richard "Duns Scotus and Suárez at the Origins of Modernity". In: HANKEY, Wayne J. (ed). Deconstructing Radical Orthodoxy. Postmodern Theology, Rhetoric and Truth. Aldershot: Ashgate, 2005, p. 65-80.

DELUMEAU, Jean. A confissão e o perdão. São Paulo: Companhia das Letras, 1998.

FASTIGGI, Robert. Suárez and the non belivers. Pensamiento, vol. 74, n. 279, p. 263 $270,2018$.

HEREDIA, Vicente Beltrán de. La actuación del Maestro Domingo Báñez en la Universidad de Salamanca. Ciencia tomista, n. 25, 1922.

Domingo Bañez y las controvérsias sobre la gracia: textos y documentos, Salamanca, Biblioteca de los teólogos españoles, 1968.

HESPANHA, Manuel. Imbecillitas. As bem-aventuranças da inferioridade nas sociedades de Antigo Regime. São Paulo: Annablume, 2010.

JEDIN, Hubert. Historia del concilio de Trento. Pamplona: Ediciones Universidad de Navarra, 1972.

LAEMERS, Joroen Joseph. Invincible ignorance and the discovery of the Americas: the history of an idea from Scotus to Suárez. PhD (Doctor of Philosophy) Thesis, University of Iowa, 2011.

ECHEVARRÍA, Juan. Antonio Hevia La polémica De auxillis y la Apología de Banez: introducción a la edición española de la Apología. In: BAÑEZ, Domingo. Apología de los hermanos dominicos contra la concordia de Luís de Molina. Oviedo: Pentalfa, 2002.

LEIJENHORST, Cees. Cajetan and Suarez on Agent Sense: Metaphysics and Internal Senses and the Mind/Body Problem from Avicenna to the Medical Enlightenment. Ed Henrik Lagerlund, Dordrecht, Kluwer, 2007, p. 237-262.

MARCOCCI, Giuseppe. A consciência de um império: Portugal e seu mundo (séc. XVXVII). Coimbra: Imprensa da Universidade de Coimbra, 2012.

MARYKS, Robert Aleksander. Saint Cicero: the influence of the liberal arts on the adoption of moral probabilism. Hampshire: Ascgate (e-book), 2008.

MOLINA, Luís de. Concordia del libre arbitrio con los dones de la gracia y con la presciencia, providencia, predestinación y reprobación divinas. Oviedo: Fundación Gustavo Bueno, 2007. 
MORSE, Richard. O rei no espelho. São Paulo: Cia das Letras, 1988.

MOTA, Bento. Liberdade Tropical: o livre-arbítrio e os índios do Brasil. Dissertação (Mestrado em História Social). Universidade Federal Fluminense (UFF). Niterói, 2016.

A universalidade do conhecimento de Deus e da Lei entre os ameríndios: relações entre Francisco de Vitória e Antonio Vieira. Anais da Jornada de Estudos Históricos Professor Manuel Salgado, PPGHIS-UFRJ, 14. ed., v. 5, Rio de Janeiro, 2019, p. 509-521.

MULLET, Michael. A Contra-Reforma e a Reforma católica nos princípios da Idade Moderna. Lisboa: Gradiva, 1985.

O'MALLEY, John. W, Trent and all that: renaming Catholicism in the Early Modern Era. Cambridge, Massachusetts: Harvard University Press, 2000.

PALOMO, Federico. A Contra-Reforma em Portugal (1540-1700). Lisboa: Horizonte, 2006.

PRODI, Paolo. Uma história da justiça: do pluralismo dos foros ao dualismo moderno entre consciência e direito. Tradução de Karina Jannini. São Paulo: Martins Fontes, 2005.

PROSPERI, Adriano. El concilio de Trento: una introducción histórica. Valladolid, Junta Castilla-León, 2008.

Scienza e immaginazione teologica nel Seicento: il battesimo e le origini dell'individuo, In "Quaderni Storici”, 1999.

Tribunais da Consciência. São Paulo: Unesp, 2014.

RUIZ, Rafael, Sal da consciência: Probabilismo e Justiça no mundo ibérico, São Paulo: Editora Raimundo Lulio, 2015.

SCHMAUS, M. Teología dogmática Madrid: Rialp, v. V, 1959.

SIENRA, García de La, "El libre albedrio y la gracia: Molina, Suárez y la Reforma". In: CARDOSO, Adelino. Francisco Suarez: Tradição e Modernidade. Lisboa: Colibri; Universidade de Lisboa, 1999, 265-278

SUÁREZ, Francisco. De Legibus: sobre a lei em geral. Lisboa: Tribuna, 2004.

STEGMÜLLER, Friedrich. Francisco de Vitoria y la doctrina de la gracia en la Escuela salmantina. Barcelona, 1934. p. 166-482.

SUÁREZ, Francisco. Dysputationes metaphysicae (1597). In: MEIRINHOS, José Francisco (Org.). As disputas metafísicas de Francisco Suárez, Famalicão: Univ. de Letras do Porto, 2011. 
SUÁREZ, Francisco. De Voluntario et Involuntario. In: Opera Omnia. Paris: Ludovicum Vivès, 1858.

. Tractatus de Fide. In: Opera Omnia. Paris: Ludovicum Vivès, 1858.

Tractatus de Legibus ac Deo. In: Opera Omnia. Paris: Ludovicum Vivès, 1858.

A work of three theological virtues faith, hope and charity. In: PINK, Thomas (ed.). Selections from three. Indianopolis, 2015.

De Legibus: sobre a lei em geral. Lisboa: Tribuna, 2004.

SUÁREZ, Francisco. Tratado de las leyes y de Dios legislador. Trad. por Jaime Torrubiano Ripoll. Madrid: Reus, 1918-1921, X volumes, Livro II, cap. IX.

SCHMUTZ, Jacob "¿ Abatir o ensalzar a Francisco Suárez ?". In: Francisco Suárez, éste es el hombre. Valencia: Facultad de Teología San Vicente Ferrer (Analecta Valentina, 50), 2004a, p. 5-16.

SPROUL, R. C. Sola gratia: a controvérsia sobre o livre-arbítrio ao longo da história, São Paulo: Cultura Cristã, 2001.

TALLON, Alain. Le concile de Trente. Paris, Cerf, 2010.

TORGAL, Luís Reis. Ideologia Política e Teoria do Estado na Restauração. Coimbra: Universidade de Coimbra, 1981, 2 vol.

TUTINO, Stafania. Uncertainty in Post-Reformation Catholicism: A History of Probabilism, Oxford: Oxford University Press, 2017.

VILLEY, Michel. A formação do pensamento jurídico moderno. São Paulo: Martins Fontes, 2009.

Artigo recebido em 10 de janeiro de 2020. Aprovado em 14 de fevereiro de 2020. 